\begin{tabular}{|c|c|c|c|}
\hline $\begin{array}{c}\text { Table } 2 . \\
\text { or CD } \\
\text { A. }\end{array}$ & $\begin{array}{l}\text { OMETRY OF } \\
\text { Fig, angle }\end{array}$ & $\begin{array}{c}\text { HYBRID METHY } \\
I \text { (CHD) } \\
\times 10^{-60} \mathrm{gm} . \mathrm{cm}^{2}\end{array}$ & $\begin{array}{l}\text { RADIOAL } \\
\text { Deviation } \\
\text { from } y \text {-axis }\end{array}$ \\
\hline $\begin{array}{l}1 \cdot 105 \\
1 \cdot 095 \\
1 \cdot 071\end{array}$ & $\begin{array}{l}137^{\circ} 20^{\prime} \\
140^{\circ} \\
147^{\circ} 54^{\prime}\end{array}$ & $\begin{array}{l}\mathbf{5} \cdot \mathbf{2 6 2} \\
\mathbf{5} \cdot 252 \\
\mathbf{5} \cdot 230\end{array}$ & $\begin{array}{l}6^{\circ} \quad 50^{\prime} \\
6^{\circ} \mathbf{1 5}^{\prime} \\
4^{\circ} \quad 46^{\prime}\end{array}$ \\
\hline
\end{tabular}

it may be expected that the corresponding carbon hydrides should also be located within the $\operatorname{same}$ framework in similar manner.

From the rotational constants ${ }^{2} B^{\prime \prime}\left(\mathrm{CD}_{2}\right)=3.96$ and $B^{\prime \prime}(\mathrm{CHD})=5.33 \mathrm{~cm} .^{-1}$, the principal moments of inertia of the CHD radical are found to be: $I\left(\mathrm{CD}_{2}\right)=$ $7.084 \times 10^{-40} \mathrm{gm} . \times \mathrm{cm}^{2}$ and $I(\mathrm{CHD})=5 \cdot 247 \times$ $10^{-40} \mathrm{gm} . \times \mathrm{cm}^{2}$. In the latter case, the figure axis inclines slightly from the $y$-axis of the co-ordinate system. The comparison shown in Table 2 indicates that neither the measured distance (1.071 $\AA$.) nor the predicted value $(1 \cdot 105 \AA$.) is satisfactory. It can also be seen that a carbon-hydrogen distance of $1.095 \AA$. yields $I(\mathrm{CHD})=5.252 \times 10^{-40} \mathrm{gm} . \times \mathrm{cm} .{ }^{2}$, which checks the experimental value. However, the results rest on the assumption that the experimentally determined rotation constants are correct. Unless the two radicals under discussion show some extraordinary electron configurations, it is expected that the present prediction and final experiment must ultimately agree. No detailed calculations have been made for the methyl radical.

\section{George Grockler}

Department of Chemistry,

Duke University, Durham,

North Carolina.

1 Herzberg, G., Proc. Chem. Soc., Lond., 116 (1959).

s Herzberg, G., Nature, 183, 1801 (1959)

3 Glockler, G., Seventeenth Intern. Union Pure and App. Chem. Cong., Munich (1959) (Butterworths, London, in the press); $J$. Phys.
Chem., 61, 31 (1957).

\section{Polarographic Determination of Vanillin}

VARIous physico-chemical and chemical methods have been used for the determination of vanillin. Of the volumetric methods ${ }^{1}$, the oxime method has been modified in many ways, whereby either the quantity of the hydrochloric acid set free in the reaction of hydroxylamine hydrochloride with vanillin, or the quantity of the unreacted hydroxylamine, is titrated visually or potentiometrically. Colorimetric methods are based on the slight reducing capacity of phenols ${ }^{2}$, the polarographic methods ${ }^{3}$ on the reduction of the aldehydic group of vanillin.

I have devised a new method for the determination of vanillin by utilizing the condensation of the aldehydic group with hydroxylamine with formation of the oxime, according to the following scheme :<smiles>COc1ccc(C=O)cc1O</smiles><smiles>COc1cc(O)cc(/C=N/O)c1</smiles>

The resulting oxime is polarographically active. The condensation of the aldehydic group proceeds quantitatively and the resulting oxime is reduced at more positive potentials. The sensitivity of the method is twice that of the direct polarographic determination. The condensation as well as the

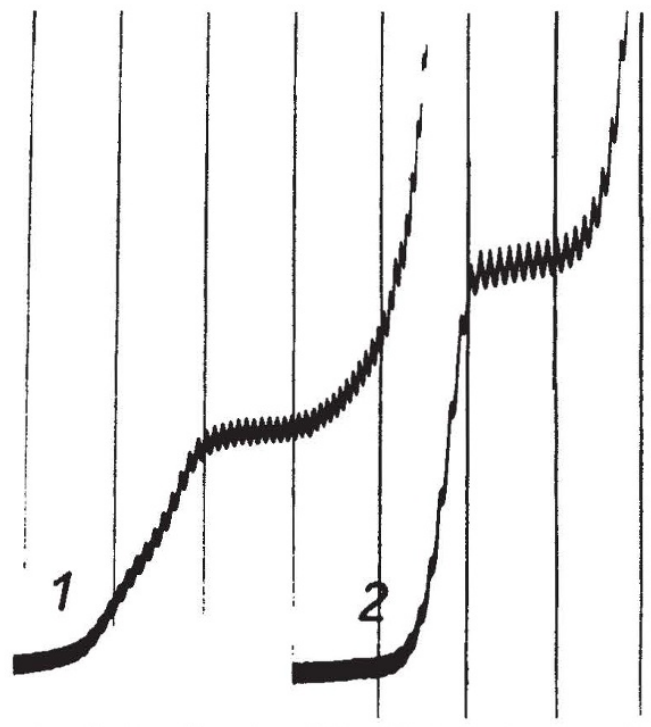

Fig. 1. Condensation of vanillin with hydroxylamine. Curve 1: 5 ml. $0 \cdot 1 M$ ammonium chloride $+5 \mathrm{ml} .1 \times 10^{-3} M$ vanillin $5 \cdot 9+5$ ml. $1 \times 10^{-3} M$ vanillin solution +1 ml. $1 M$ hydroxylamine hydrochloride, from $-0.78 \mathrm{~V}$. Saturated mercurous sulphate electrode, sensitivity $i$ : $30,195 \mathrm{mV}$./absc.

reduction of vanillin oxime proceed best in a phosphate buffer of $p \mathbf{H} \mathbf{5 \cdot 9}$. Under these conditions, the height of the oxime wave is precisely double that of vanillin before condensation (Fig. 1).

In phosphate buffer of $p \mathbf{H} \mathbf{5 . 9}$, vanillin is reduced at a half-wave potential of $-0.93 \mathrm{~V}$. (sat. calomel electrode) in a single well-developed four-electron wave. The dependence of the height of the oxime wave is a linear function of the concentration of vanillin. The wave shows a diffuse character, is easy to read and suitable for analytical use.

A detailed account of the reaction conditions and of the utilization of the method for the analysis of vanillin, both in the pure state and in foods, will be described elsewhere.

Department of Chemistry and Jrǩ́ Davfoek Control of Food

Institute of Chemical Technology, Prague.

${ }^{1}$ Sharp, L. K., Analyst, 76, 215 (1951). Böhme, H., and Winkler, O., Z. Lebensm. - Vntersuch. u Forsch., 99, 22 (i954). Martin, Sci. Ed., 35, 220 (1940). Berka, A., and Zyka, J., Ceskoslov. farm., 6, 335 (1956); Chem. listy, 50, 13i (1956).

${ }^{2}$ Wilson, J. B., J. As8oc. Offic. Agric. Chemists, 25, 155 (1942) Englis, D. T., and Manchester, N., Anal. Chem., 21, 591 (1949). 3 Winkel, A., and Proske, G., Ber, deut. chem. Ges., 69, 1917 (1936).

Brdicka, R., Cas. ces. lëkárnictva, ¿̌éd. phl., 58, 37 (1956).

\section{Spectrophotometric Determination of the Electron Affinities of Some Diatomic Molecules}

ThE purpose of this communication is to present a calculation of the electron affinitios of some molecules from charge transfer spectra. Mulliken's ${ }^{1}$ theory for a charge-transfer process leads to the expression :

$$
h v_{\max }=I_{D}-E_{A}-\Delta
$$

where $h \nu_{\max }$ is the energy corresponding to the most probable electronic transition, $I_{D}$ and $E_{A}$ are the vertical ionization potential of the electron 